\title{
Borrowers' Distress and Debt Relief: Evidence from a Natural Experiment
}

\author{
Saptarshi Mukherjee New York University \\ Krishnamurthy Subramanian Indian School of Business \\ Prasanna Tantri Indian School of Business
}

\begin{abstract}
Using unique borrower-level data, we study the causal effect of debt relief on the loan performance of distressed and nondistressed borrowers. We employ a regression discontinuity design that exploits exogenous cutoff dates underlying the 2008 Indian debt waiver program to separate defaulters on loans into beneficiaries and nonbeneficiaries of waivers. By identifying distress before the waiver program using exogenous borrower-level shocks, we examine performance on loans originated after the waiver program. Loan performance of nondistressed beneficiaries worsens, while that of distressed borrowers improves. While existing studies aggregate the effects of debt relief across distressed and nondistressed borrowers, we highlight crucial differences between them.
\end{abstract}

\section{Introduction}

In this study, we examine the differential impact of debt relief on distressed and nondistressed agricultural borrowers. We use unique data at the borrower level and utilize the natural experiment provided by the $\$ 14.4$ billion debt waiver program in India in 2008. We show that heterogeneity among borrowers-specifically, borrowers' distress-affects the outcome of a debt waiver program.

Across the world, governments institute programs for debt relief and forgiveness during times of economic distress. One of the first legal codes-the Code of Hammurabi enacted in 1772 BCE-advocates such relief (Mian and Sufi 2014). Apart from the Indian debt waiver program that we study, recent examples of

We would like to thank Dhammika Dharmapala and two anonymous referees for their thoughtful feedback. We would also like to thank Viral Acharya, Prachi Deuskar, Sudip Gupta, James Vickery (Financial Intermediation Research Society conference discussant), and seminar and conference participants at the Indian School of Business finance seminar, the 2015 Financial Intermediation Research Society Conference, and the 2015 Salomon Center at New York University and Moody's Corporation Credit Risk Conference for valuable comments. The usual disclaimer applies.

[Journal of Law and Economics, vol. 61 (November 2018)]

(c) 2018 by The University of Chicago. All rights reserved. 0022-2186/2018/6104-0020 $\$ 10.00$ 
such interventions include the US $\$ 2.9$ billion bailout for farmers in Thailand and the rescheduling of about US $\$ 10$ billion of agricultural debt in Brazil.

Debt relief relies on the simple idea that debt overhang can debilitate poor households and, thereby, the overall economy through general equilibrium effects (Mian and Sufi 2014). In emerging economies, debt relief assumes particular significance, as a large proportion of the households remain not only poor but also vulnerable to income shocks. ${ }^{1}$ In India, for example, farmers' suicides attributable to local rainfall shocks and high indebtedness have reached alarming levels, with more than 59,000 deaths over the last 10 years (see Carleton 2017).

When compared with fiscal transfers or tax breaks, evaluating the effects of an intervention in the credit market poses significant challenges. On the one hand, debt contracts are highly incomplete, as they do not provide for contingencies arising from an adverse state that is beyond borrowers' control (Bolton and Rosenthal 2002). On the other hand, an intervention in the credit market can potentially alter borrowers' behavior-specifically, prudent borrowing and repayment habits-by changing borrowers' beliefs about future interventions. While disentangling such opposing forces is inherently difficult, the key empirical challenge stems from the net effect of these forces being heterogeneous. So average effects estimated using aggregated data can hide important heterogeneity in the effects of debt relief. Indeed, recent work on macroeconomic models with heterogeneous agents shows that the impact of stimulus programs may be misunderstood if heterogeneity among beneficiaries is not taken into account. ${ }^{2}$

We study one key aspect of heterogeneity in borrowers-a priori distress-in examining the effect of debt relief. We consider borrowers who default on their loans because of liquidity shocks caused by exogenous events to be distressed borrowers. Other defaulters are considered to be nondistressed borrowers. Among the nondistressed borrowers, we do not distinguish between strategic defaulters and those who have long-term balance sheet issues, plausibly caused by borrowers' poor inherent quality. Crucially, we identify borrowers' distress prior to debt relief and then carefully compare beneficiaries of debt relief with otherwise identical borrowers who could not receive debt relief for exogenous reasons.

On February 29, 2008, the Indian government announced a debt waiver program for past defaulters. In absolute terms, this debt waiver program ranks as the largest in an emerging market, and as a percentage of gross domestic product, the program ranks as the largest ever worldwide. This program waived the debt of about 40 million farmers, a group that is greater than the population of 85 per-

\footnotetext{
${ }^{1}$ Jacoby and Skoufias (1997) show that exposure to repeated weather shocks affects households across generations. For example, school attendance of children living in households exposed to income shocks resulting from weather shocks is lower than that of children living in low-exposure households. See also Deaton (2016, 1989), Datt and Hoogeveen (2003), and Burgess et al. (2011).

${ }^{2}$ Recent evidence on fiscal stimulus programs in the United States led to a revision of the celebrated permanent-income hypothesis, as a large part of the transfers were spent in the same quarter, primarily on nondurable items. Moreover, the response to these transfers varied significantly, with 0 marginal propensity to consume for one group and .5 for other groups. Using this evidence, Kaplan and Violante (2014) hypothesize the existence of wealthy hand-to-mouth agents, who form a larger proportion of the economy than poor hand-to-mouth agents.
} 
cent of the countries in the world, including Canada, Iraq, and Poland. The average loan amount waived equaled approximately 60 percent of a farm household's annual income.

We use some distinctive features of the program to study its effects. First, as we describe in Section 3, the waiver program was an unanticipated event. Second, though the waiver was announced on February 29, 2008, it was awarded only to borrowers who had defaulted 2 months before, as of December 31, 2007, and who continued to be in default as of February 29, 2008. Beneficiaries could neither have defaulted in anticipation of the waiver nor self-select into the program. Thus, the assignment of borrowers into groups of beneficiaries and nonbeneficiaries was exogenous to the program.

We employ a unique loan-level data set provided to us by a bank in India. The data start in October 2005 and end in May 2012, which provides us with a good before-and-after sample. The data pertain to crop loans with a tenure of exactly 1 year. The loans do not have any interim coupon payments; they must be repaid in full in one installment within 1 year of borrowing. These bullet loans enable us to cleanly identify the due date of a loan's repayment and default. A loan is considered to be in default if it is not fully repaid on the due date. Our data contain information about the date of a loan's issuance, the loan's amount, the date of repayment, the amount to be repaid, and the interest and/or penalty charged on the loan. We hand collect data from 14 bank branches located in three large states, which account for nearly one-sixth of India's population.

We use a sharp regression discontinuity (RD) design to study the causal effects of debt relief. As Lee and Lemieux (2010, p. 282) argue, citing Hahn, Todd, and Van der Klaauw (2001), "RD designs require seemingly mild assumptions compared to those needed for other non-experimental approaches." We exploit the fact that the waiver was awarded to only those borrowers who defaulted on a loan on or before December 31,2007, and continued to be in default until February 29,2008 . December 31, 2007, which has no significance for agricultural production in India, serves as the sharp cutoff date. Think of two borrowers who each borrowed a 1-year crop loan on December 30, 2006, or January 1, 2007. Assume that both borrowers defaulted on their loans. Also assume that both the loans remained overdue on February 29, 2008. As per the rules of the waiver program, the first borrower is eligible for a waiver, but the second borrower is not. Thus, borrowers separate into beneficiaries and nonbeneficiaries on the basis of the artificial cutoff date. As we describe in Section 3.3, the program was completely unanticipated. Also, in Section 6.4.1, we reason that borrowers could not manipulate their way into the treatment group, and we follow McCrary (2008) to provide evidence consistent with this idea. As the crop loans are of 1-year maturity, a borrower would have to anticipate the waiver program by December 30, 2006-14 months before it was announced-so that he could insist on the loan being originated before that date. Such advanced preparation and anticipation are implausible when the borrower is the owner of a small farm.

Using crop loans provided after the waiver program to the same set of bor- 
rowers who had defaulted before the waiver, we compare the loan performance of beneficiaries vis-à-vis similar nonbeneficiaries. By design, all borrowers in the RD sample had defaulted on a loan before the waiver program was implemented. The RD tests thus exogenously separate borrowers who defaulted in treatment and control groups by the date on which the loan went into default. We examine the performance on the loans given to those borrowers after the implementation of the waiver program. Beneficiaries and nonbeneficiaries of waivers (hereafter, waiver beneficiaries and nonbeneficiaries) do not differ significantly in the probability of obtaining a loan after the waiver program. Thus, the tests alleviate concerns that our results are driven by possible substitution effects that could occur when a new set of borrowers gets a loan after the waiver program was instituted.

We use farmers who filed a claim for crop insurance before the waiver program as a proxy for distressed borrowers. As we discuss in detail in Section 3, crop insurance indemnifies loss resulting from pests, crop diseases, and natural disasters such as fire, lightning, inundation, landslide, drought, and dry spells (Ministry for Agriculture and Farmers Welfare 2000). We make the reasonable assumption that a borrower who files for and receives payment for a crop insurance claim is affected by one of these exogenous shocks. To avoid fake claimants, we do not classify as distressed borrowers whose insurance claims were rejected.

The presence of crop insurance, however, cannot substitute for the effect of debt waivers to distressed borrowers. During our sample period, crop insurance was heavily subsidized in India. Hence, the government restricted significantly the sum assured. In fact, the average claim-to-loan ratio in our sample is significantly lower than 10 percent. In addition, the borrower typically received the payout after a significant delay, sometimes up to 2 years after filing the claim. Therefore, while filing a claim credibly signals borrowers' distress due to an exogenous shock, receiving an insurance payout does not ameliorate the consequences of such a shock. So crop insurance cannot substitute for the possible benefits of a debt waiver to distressed borrowers. In contrast, defaulting borrowers who did not file insurance claims before the debt waiver program-despite possessing crop insurance-plausibly did not suffer from an exogenous shock. ${ }^{3}$ As a sanity check, we test and find that borrowers who make crop insurance claims default on their bank loans more often than other subscribers of crop insurance and that there is no significant discontinuity in insurance claims around the exogenous cutoff date for the RD model.

We find that distressed waiver beneficiaries default 9 percent less on the loans issued to them after the waiver program than do other comparable (distressed) nonbeneficiaries. In contrast, nondistressed waiver beneficiaries default 23 percent more than comparable (nondistressed) nonbeneficiaries. These results in-

\footnotetext{
${ }^{3}$ Note that we do not claim that uninsured shocks cannot create distress for borrowers. However, as the insured factors dominate the risks faced in agriculture in an emerging economy, defaulting borrowers who file insurance claims are more likely to have suffered an exogenous liquidity shock than defaulting borrowers who do not file insurance claims. Moreover, the incidence of an uninsured shock is unlikely to vary systematically either with the cutoff date for the regression discontinuity model or between farmers whom we categorize as distressed and nondistressed.
} 
dicate that debt relief is helpful when a borrower defaults because of exogenous liquidity shocks. However, when default is likely to be caused either by structural balance sheet issues or by strategic behavior, debt relief is likely to be counterproductive, as it is likely to fuel further default. We derive these implications from a stylized model presented in Online Appendix OA.

We perform multiple sets of robustness tests. First, we argue that measurement error created by our borrower-level proxy for distress does not affect our results. The measurement error would have to account simultaneously for the improved loan performance of distressed beneficiaries and the worse loan performance of nondistressed beneficiaries due to the waiver program. This is implausible, especially given the exogenous cutoff date that separates beneficiaries and nonbeneficiaries. Second, we measure distress at the branch level as an orthogonal proxy to the borrower-level measure and find that our results remain unchanged. Not only do these tests alleviate residual concerns about measurement error affecting our results, but they also exhibit the robustness of our results to alternative definitions of distress. Third, we provide support for an important identifying assumption underlying the RD design; that is, there is no discontinuity in baseline characteristics. Finally, because we compare the performance of new loans issued after the waiver program with that of loans issued before the waiver program, a potential concern may be that the quality of borrowers receiving loans after the waiver program may systematically influence our results. We show that about 90 percent of farmers borrow again after the waiver program and that there is no discernible difference between the beneficiaries of the debt waiver program and the nonbeneficiaries. We also find that the loan amounts and other loan terms did not change materially after implementation of the waiver program. These results mitigate the concern that our key finding stems from potential selection bias.

Our results suggest policy implications that are more nuanced than those suggested by existing empirical studies. First, consistent with the theoretical arguments in Bolton and Rosenthal (2002) and in the poverty-trap theories (Banerjee and Newman 1993; Mookherjee and Ray 2003), debt relief targeted at distressed beneficiaries is likely to improve loan performance. Thus, governments may not necessarily be wasting scarce fiscal resources to serve their narrow political interests if a debt waiver is targeted toward distressed borrowers. In fact, though the economic environment we study comprises agricultural loans in an emerging country, our findings and the attendant policy implications are similar to those in Mian and Sufi (2014), which contends that the lack of debt forgiveness for housing loans exacerbated the Great Recession. Second, a debt waiver that is granted to all borrowers - whether distressed or not-can not only waste scarce fiscal resources but also be counterproductive by increasing loan defaults.

\section{Review of the Literature}

To the best of our knowledge, ours is the first empirical study to examine the causal effect of debt relief on distressed and nondistressed borrowers (in the same 
program). Our study relates closely to Kanz (2016) and Giné and Kanz (2018), who also study the Indian debt waiver program of 2008. Kanz (2016) and Giné and Kanz (2018) document the costs associated with the debt waiver program. Kanz (2016) uses household surveys to show that the debt waiver program reduced the investment and agricultural productivity of the benefiting households. Giné and Kanz (2018) use aggregate data at the district-bank level to show that the debt waiver program decreased the loan performance of all beneficiaries, especially in districts where the level of exposure to the program was high. Our study highlights that the aggregate effects estimated by Kanz (2016) and Giné and Kanz (2018) hide substantial heterogeneity in the effects of a debt waiver program, especially depending on whether or not the borrower is distressed. When assessing the policy impact of a debt waiver program, incorporating such heterogeneity is particularly important if indebtedness among borrowers is widespread.

Several recent studies examine the costs and benefits of debt relief using different types of bankruptcy laws. Demiroglu, Dudley, and James (2014) show that debt relief provided by several US states during the housing crisis enhanced the likelihood of default on housing loans. Goodman and Levitin (2014) show that modifying the principal in chapter 13 filings increases the interest rates for consumers. Other studies examine the costs and benefits of debt relief using different types of bankruptcy laws (Dobbie and Song 2015; Athreya 2002; Chatterjee and Gordon 2012; White 1998, 2007). These studies argue that debt relief programs help achieve smoothing across different states of the world, possibly at the expense of intertemporal smoothing (Livshits, MacGee, and Tertilt 2007; Dubey, Geanakoplos, and Shubik 2005; Tabb 1995; Skeel 2001; Bolton and Rosenthal 2002; Kroszner 2003). However, not only does a borrower choose to declare bankruptcy, but the decision to file for bankruptcy is also influenced significantly by credit market conditions (Cohen-Cole, Duygan-Bump, and MontoriolGarriga 2009). Thus, in these studies, it is difficult to disentangle the impact of debt relief from endogenous circumstances faced by the borrower (Dobbie and Song 2015; Dick and Lehnert 2010) or endogenous market conditions.

Given these limitations, several scholars examine large-scale government debt relief programs granted during harsh economic circumstances (Rucker and Alston 1987; Agarwal et al. 2017). While some studies find that such programs result in modest benefits (Agarwal et al. 2017), others show that such programs induce moral hazard and do not lead to any improvements in real outcomes (Kanz 2016; Giné and Kanz 2018; De and Tantri 2014). Arguing the benefits of debt relief, Mian and Sufi (2014) in fact contend that the lack of debt forgiveness exacerbated the Great Recession. Most of these studies, however, focus on either the benefits of debt relief to distressed borrowers (Bolton and Rosenthal 2002) or the costs created by strategic borrowers (Mayer et al. 2014; Guiso, Sapienza, and Zingales 2013; Kanz 2016; Giné and Kanz 2018). This is because it is difficult to separate distressed borrowers from nondistressed or strategic ones ex ante. We contribute to this literature by exploiting a natural experiment to highlight the differential effect of debt relief on distressed and nondistressed borrowers. 


\section{Institutional Background}

\subsection{Agricultural Lending in India}

Three key factors characterize the agricultural credit markets in emerging economies like India. These factors are risk, scarce collateral with poor enforcement of creditors' rights, and state control of banking.

\subsubsection{Significant Exposure to Risk}

Agricultural lending in a developing country like India exposes farmers to significant risks. These risks result from the income stream from agriculture remaining highly uncertain (Deaton 1989, 2016), weather shocks creating significant risks and leading to permanent high levels of distress among farmers (Jacoby and Skoufias 1997; Datt and Hoogeveen 2003; Burgess et al. 2011), and farmers being significantly underinsured against crop losses caused by weather shocks.

Nearly 44.1 percent of small-farm owners in India are illiterate (Mahadevan and Suardi 2013). Thus, they are generally unaware of technological developments for risk mitigation in farming. The farms in our sample are quite small, less than 2 hectares. Small-farm owners are less likely to use modern technology, which involves fixed costs in learning and in financial investment. Given the size of their landholdings, such fixed costs are disproportionately high.

\subsubsection{Scarce Collateral and Poor Enforcement}

A common solution to mitigate strategic default is to have the borrower post a physical asset as collateral that can be appropriated in case of default. However, most farmers in emerging economies are too poor to post substantial collateral other than land or the expected crop. Poorly delineated property rights over land exacerbate the problem by making it difficult for the bank to foreclose on land that has been put up as collateral for a loan. Moreover, foreclosing on a farmer's land is politically sensitive, as local politicians, across party lines, intervene on behalf of farmers irrespective of the merits of a case. ${ }^{4}$ In addition, the judicial process is extremely slow. ${ }^{5}$ In effect, farmers in India do not face the threat of their land being taken by their lenders, which encourages strategic default.

\subsubsection{State-Controlled Banking System}

The Government of India plays a dominant role in the banking sector: approximately 71 percent of the banking system (as measured by assets) is owned by the

\footnotetext{
${ }^{4}$ In one such incident in Mysore, Karnataka, the lender was forced to return a tractor repossessed from a farmer after the farmer committed suicide. The local politicians alleged that the suicide was due to "arm-twisting" tactics employed by recovery agents of the bank (Hindu 2008).

${ }^{5}$ A World Bank survey ranks India 132 of 183 in terms of ease of doing business (World Bank 2012, p. 6). In terms of enforcement of contracts, India is ranked 182 of 183 countries surveyed, and it takes on average 1,420 days to enforce a contract. In comparison, in Singapore the same contract enforcement takes just 150 days (World Bank 2012, pp. 101, 125).
} 
government. The Indian government nationalized many private banks in 1969 and 1980 and enacted several regulations to improve access to finance by critical sectors and by vulnerable sections of the population. Priority-sector lending guidelines require that at least 18 percent of a bank's credit be directed to agriculture (Bhue, Prabhala, and Tantri 2015).

\subsubsection{Agricultural Loans in India}

As agricultural loans come under the purview of priority-sector lending, the rate of interest applicable for these loans is 7 percent, which is approximately 200 basis points lower than the risk-free rate prevailing during our sample period and approximately 400 basis points lower than the bank deposit rate during our sample period. We examine crop loans for which the underlying crop is rice. These bullet loans, which the borrower repays with accrued interest at the end of 12 months, require no intermediate payments. However, not every overdue loan (outstanding for more than 365 days) is considered to be a nonperforming asset. As per guidelines issued by the Reserve Bank of India (2004), crop loans are recognized as nonperforming assets only if they remain overdue for at least two crop seasons.

\subsection{Crop Insurance in India}

The Comprehensive Crop Insurance Scheme was introduced in India in 1985. The purpose of the scheme was to indemnify farmers in the event of a failure of crops as a result of natural calamities. The scheme was limited to farmers who availed themselves of crop loans. In 1999-2000, the Government of India introduced the National Agricultural Insurance Scheme (NAIS), which aimed to cover all farmers. The Ministry of Agriculture reports that the NAIS has covered about 269.1 million farmers. Claims worth INR 506.1 billion have been paid so far. The insurance scheme is heavily subsidized, with 75 percent of the premium paid by state and federal governments. ${ }^{6}$ The scheme indemnifies loss resulting from natural events including fire, lightning, inundations and landslides caused by excessive rainfall, droughts and dry spells, pests, diseases, and the like. The state government is expected to determine the normal yield through surveys and experiments; the loss is then determined by comparing actual production with normal production. A claim's amount is the lower of the loss caused and the sum assured. To avoid a burgeoning subsidy burden, the government sets the sum assured under the NAIS to be quite low. In fact, we find that the insurance claim amount is less than 10 percent of the loan amount in our sample. As a result, the amount indemnified under the NAIS does not make a meaningful difference to farmers' liquidity.

\footnotetext{
${ }^{6}$ Government of India, Department of Agriculture Cooperation and Farmers Welfare, National Agricultural Insurance Scheme (http://agricoop.gov.in/divisiontype/progress/national-agricultural -insurance-scheme-nais).
} 


\subsection{India's Debt Waiver Scheme of 2008}

As a part of the financial budget speech delivered on February 29, 2008, the finance minister of India announced an unprecedented bailout of indebted smallhold and marginal farmers. The Debt Waiver and Debt Relief Scheme for Small and Marginal Farmers affected about 40 million farmers and provided subsidies worth approximately INR 715 billion (US\$14.4 billion) (De and Tantri 2014). The average loan waiver of approximately $\$ 360$ amounted to 60 percent of a farm household's annual income. ${ }^{7}$ All formal agricultural debt disbursed by commercial and cooperative banks between 1997 and 2007 came under the purview of this scheme. Agricultural loans that were either overdue or restructured (after being overdue) as of December 31, 2007, and continued to be overdue till February 28,2008 , qualified for the debt waiver program. Thus, no borrower who satisfied the eligibility criteria was refused a waiver. The government set a deadline of June 30, 2008, for implementation of the program.

The debt waiver scheme was an unanticipated event. First, concerned with the dismal performance of the agricultural sector and rising numbers of suicides of farmers, ${ }^{8}$ the Government of India set up a high-powered committee (the Radhakrishna Committee) "to look into the problems of agricultural indebtedness in its totality and to suggest measures to provide relief to farmers across the country” (Reserve Bank of India 2008, p. 1). In its 2007 report, the committee recommended setting up a government fund to provide loans to the farming community. However, the committee did not recommend a loan waiver program. Second, the previous national-level debt waiver program was announced about 2 decades earlier, in 1990. Though five parliamentary elections were held between 1990 and 2008, unlike the current scheme, no waiver program was announced prior to the elections. Finally, media reports before the 2008 budget was released did not mention the debt waiver program as a prominent expectation.

Crucially, in our setting, borrowers could not qualify for the program by acting strategically after the announcement was made on February 29, 2008. This is because a loan's status as of December 31, 2007, was used to decide whether a borrower qualified for a loan waiver. As all crop loans have a maturity of 1 year, borrowers who defaulted on their loans on or before December 31, 2007, should have borrowed their loans before December 31, 2006-14 months before the announcement of the program. Thus, concerns about self-selection around the cutoff (Imbens and Lemieux 2008) are significantly ameliorated.

Full waivers were granted to qualifying borrowers who had pledged 2 hectares of land or less, and partial relief, limited to 25 percent of the outstanding amount, was granted to borrowers who had pledged more than 2 hectares of land. In addi-

\footnotetext{
${ }^{7}$ The annual per capita income in rural India, which provides a reasonable proxy for the per capita income of agricultural households, equaled INR 40,772 or US\$630 in 2011-12 (Economic Times 2016).

${ }^{8}$ According to United Nations Commission on Sustainable Development (2008), more than 100,000 farmers have committed suicide since 1997, 87 percent of them after incurring an average debt of US\$835.
} 
tion, partial waivers were conditional on the borrower repaying 75 percent of the remaining balance, a difficult ask for constrained borrowers. Full waivers were implemented within 3 months of the announcement. Given the difficult conditions attached to the partial waiver, the deadline was extended several times, with only a fraction of eligible borrowers eventually participating in the waiver program. Because of timing and selection issues, the inclusion of beneficiaries of partial waivers is likely to significantly distort our analysis. Therefore, we drop those borrowers from the study and compare waiver beneficiaries with nonbeneficiaries.

\section{Hypotheses}

To clearly exposit the mechanism and derive our hypotheses, we present a simple theoretical model in Online Appendix OA. Here we illustrate the intuition using a simple numerical example. We consider a simple 2-period model in which a debt waiver is implemented at $t=0^{-}$. Borrowers differ on two dimensions. First, distressed borrowers have low level of wealth at $t=0$, as they default for liquidity reasons. In contrast, nondistressed borrowers have high level of wealth at $t=0$, as they default despite having the ability to repay. Second, some borrowers receive a loan waiver (waiver beneficiaries), while others do not (nonbeneficiaries).

Suppose the distressed and nondistressed borrowers have wealth of $\$ 20$ and $\$ 70$, respectively at $t=0^{-}$. A crop loan of $\$ 50$ provided at $t=0$ requires $\$ 50$ to be repaid in full at $t=1$ (the interest rate is normalized to 0 for simplicity). Assume that the loan waiver at $t=0$ waives the $\$ 50$ that is owed at $t=0$ from the loan that was provided at $t=-1$. In our empirical setting, borrowers repay their loans so as to receive new loans. Therefore, we assume that a borrower who repays her loan in full at $t=1$ can get a new loan of up to $\$ 75$ at $t=1$. As in the costly state-verification models, we assume that borrowers who default despite having the ability to repay are audited by a loan officer with probability $\gamma=.60$. If the borrower is found to be in violation of contractual obligations, she has to pay the entire loan amount and a 50 percent penalty (\$75 in our example). For the equilibrium to exist, we also assume that in the last period, bank audits occur with a probability of 1 , so all borrowers with the ability to pay must do so at $t=2$.

The production function follows a simple Leontief technology, in which the output of investment $k$ is given by

$$
Y=\left\{\begin{array}{ll}
1.6 \times \min (k, \bar{K}) & \text { with probability } p=.5 \\
.6 \times \min (k, \bar{K}) & \text { with probability } p=.5
\end{array}\right. \text {, }
$$

where the upper limit $\bar{K}=200$ accounts for the fact that the landholdings of the borrowers are constant and can support only a maximum capital investment.

Figures 1 and 2 show the analysis for distressed and nondistressed farmers, respectively; the detailed calculations are presented in Online Appendix OB. Intuitively, distressed borrowers suffer from debt overhang, which reduces their investment and causes them to default because of their inability to repay. Waiv- 


\section{Beneficiaries}

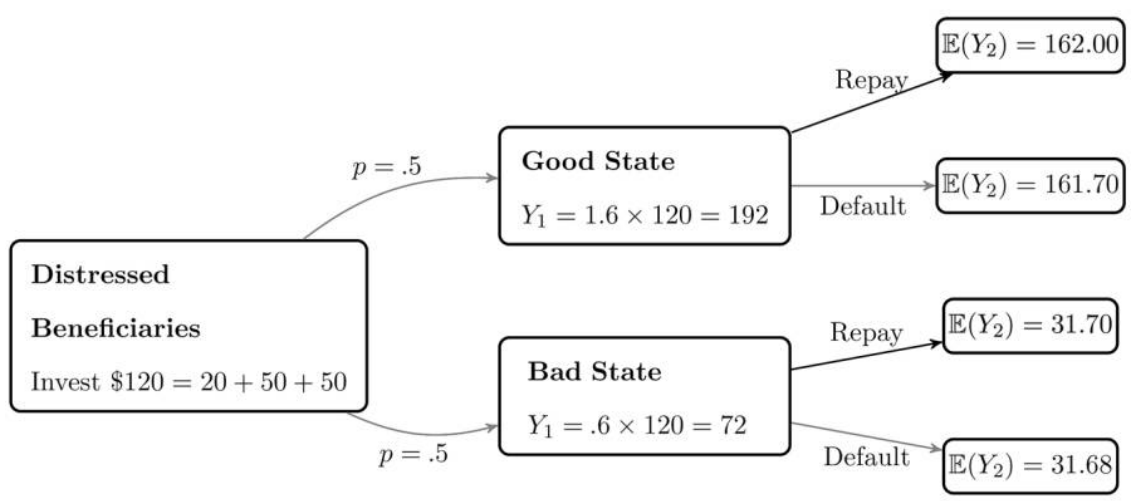

Nonbeneficiaries

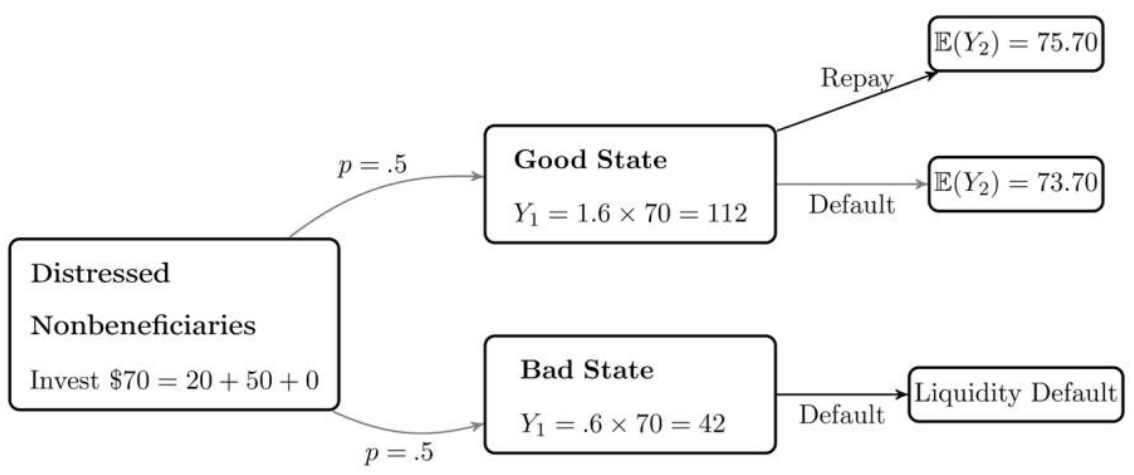

Figure 1. Theoretical model: distressed farmers

ers provide such borrowers with liquidity and alleviate the problem of debt overhang. Higher investment increases these borrowers' ability to pay and thereby improves loan performance compared with borrowers who do not receive waivers and continue to suffer from debt overhang. Therefore, waivers improve the loan performance of distressed borrowers. In contrast, as nondistressed borrowers are wealthier, waivers incentivize them to default strategically because waivers put enough cash in their hands that they can invest subsequently without having to renew their loans. Nondistressed borrowers who do not receive waivers still need loans to invest, which incentivizes them to repay their loans.

Note that, while the debt waiver is provided at $t=0$, the nondistressed borrower's incentive to take a new loan at $t=1$ is affected. So the model does not predicate issues relating to the composition or selection of borrowers at the time of the waiver, which is crucial for our empirical strategy. 


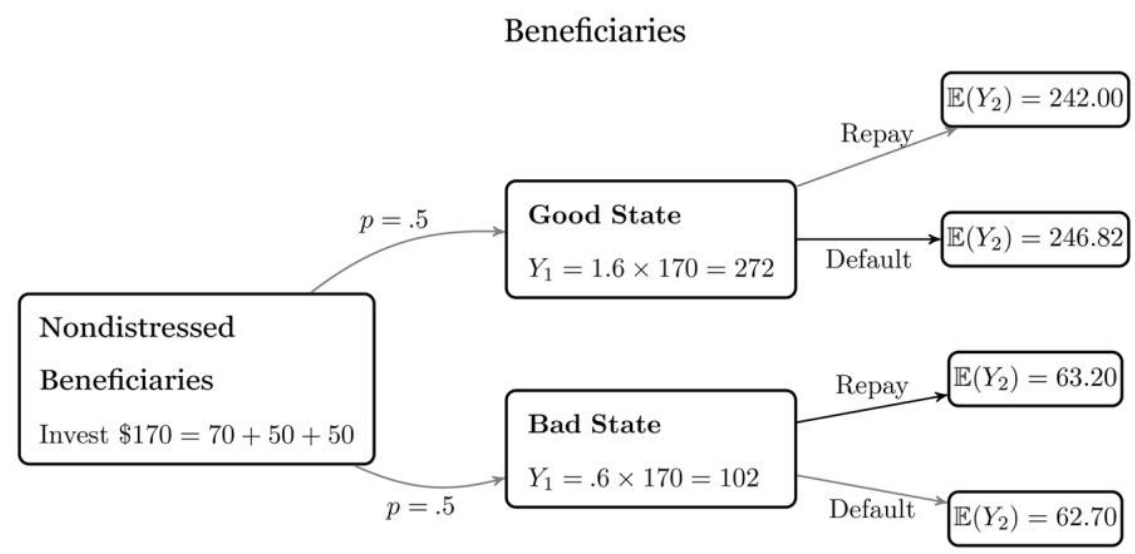

\section{Nonbeneficiaries}

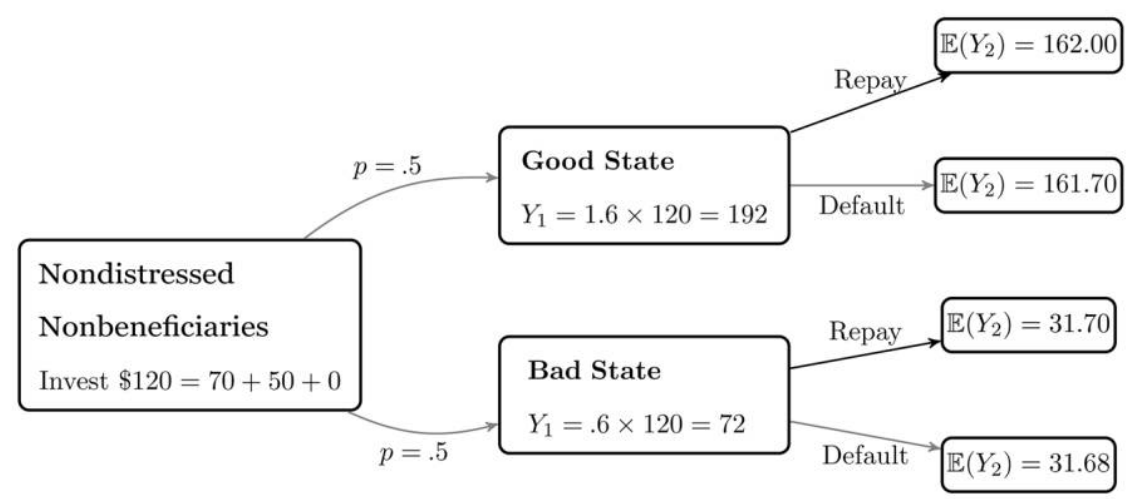

Figure 2. Theoretical model: nondistressed farmers

\section{Data and Proxies}

\subsection{Bank Loan Data}

We use unique loan-account-level information from a bank in India. We hand collect transaction-level data for 14 branches located in four districts in the state of Andhra Pradesh, two districts in Karnataka, and three districts in Maharashtra. According to the latest census, the three states together account for nearly one-sixth of India's population. We obtain loan-account-level information about all waiver beneficiaries from October 2005 to May 2012.

The transaction records provided by the bank include the date of each transaction, a short description of the transaction, the amount, the type of transaction (debit or credit), the account's balance before and after the transaction, and the type of balance (debit or credit). Using the details of the accounts, we obtain in- 
formation about the date on which a loan was obtained, the date on which it was repaid, the number of days it was outstanding, the interest charged, and so forth. All of the loans analyzed are crop loans with a 1-year maturity. We use the status of the loan (current or default) as the dependent variable. A loan that is outstanding for 365 days or more is in default. Following the Reserve Bank of India's norms, we consider a loan that has not been repaid by the due date of maturity to be in default.

\subsection{Crop Insurance Data}

Crop insurance transactions are also conducted using the loan account; thus, we have information about premiums paid and claims received. The rupee value of each transaction and the date on which it was executed are clearly recorded. In the case of claims, the description of a transaction states the date on which a claim is filed. We use the date of filing and not the date of receipt of a payout to measure distress because the borrower typically received the payout after a significant delay, sometimes up to 2 years, after filing the claim.

\subsection{Proxies for Agricultural Distress}

Distinguishing between distressed and nondistressed borrowers is key to our empirical design. We use local variation in shocks that are exogenous to the debt waiver program to distinguish between the two types of borrowers ex ante.

We consider distressed borrowers to be farmers who filed crop insurance claims during the agricultural season immediately before the waiver program was implemented. (Note that here we identify distress at the borrower level.) As described in Section 3.2, the crop insurance scheme promises to indemnify a borrower if a crop fails because of natural disasters or other factors such as crop diseases and pests. Therefore, it is reasonable to infer that a borrower who files a claim to collect crop insurance benefits must have suffered a liquidity shock that is unrelated to the debt waiver program. To exclude fake claimants, we do not consider borrowers whose insurance claims are eventually rejected.

We do not claim that crop insurance covers all kinds of distress. Instead, we make the reasonable assumption that a borrower who claims and eventually obtains a crop insurance payout is likely to be distressed. While distress could be caused by factors that are not covered by crop insurance, such as health problems, accidents, and violence in the area, our identification remains clean as long as those factors do not vary systematically between crop insurance claimants and other crop insurance subscribers and (not or) with the cutoff date for the waiver program, which is implausible. In addition, the identification strategy recognizes that different farmers could have different levels of crop realizations when faced with a similar weather shock induced by nature. The design also considers idiosyncratic shocks such as attacks by pests and crop diseases, which may impact some farms in an area but not others.

More details about the crop insurance scheme aid identification. First, to re- 
duce the subsidy burden on the government, the sum insured under the scheme is capped. A large portion of the insurance premium is paid by the federal and state governments. Under the scheme prevailing during our sample period, the insurance claims were paid on a pro rata basis. Suppose a farmer, whose normal output is 100 , suffers a loss of 20 units; then only 20 percent of the sum insured was paid (Damodaran 2016; Firstpost 2016).

This is revealed even in our sample, as the ratio of average insurance claim value to loan value is less than 10 percent. Thus, payment on an insurance claim does not ameliorate the distress caused by the insured event. Second, there is a significant delay in payment of claims. As a result, the indemnity amount that a borrower receives after filing an insurance claim does not help to alleviate the liquidity crisis for the borrower. These two facts together make filing an insurance claim a credible signal of borrowers' continuing distress.

\subsection{Association between the Insurance-Based Measure and Agricultural Distress}

Although the association between insured events and agricultural distress is well established in emerging economies (Deaton 2016), it is crucial to examine this association in our sample using our measure of distress. If indeed our measure captures distress, then it must be positively associated with default. To be sure that the incidence of filing a claim captures borrowers' distress, we run the following specification for the prewaiver period:

$$
\text { Default }_{i t}=\alpha_{i}+\alpha_{t}+\beta \times \text { Claim }_{i t}+\gamma \boldsymbol{X}_{i t}+\varepsilon_{i t},
$$

where the dependent variable equals one if a loan borrowed by borrower $i$ in year $t$ defaults and zero otherwise. The coefficient $\beta$ captures the correlation between an insurance claim being filed by borrower $i$ in year $t$ and the probability of default on a loan held by that borrower in year $t ; \alpha_{i}$ and $\alpha_{t}$ denote borrower and year fixed effects, respectively. In addition, we control for the size of the loan using the natural logarithm of the loan's amount and total rainfall during the relevant crop season.

Table 1 reports the results of equation (2), where the standard errors are clustered at the borrower level. It is evident that the binary variable indicating whether a claim was filed for year $t$ by borrower $i$ correlates very strongly with the borrower defaulting. Of course, we cannot control for other idiosyncratic shocks that are uncorrelated with production but affect the loan repayment behavior of the borrowers. For example, borrowers who have suffered personal distress, such as unexpected medical expenditures, may be more likely to default on their crop loans. Identification of such shocks is impossible without being able to access the borrowers' household balance sheets, which unfortunately we do not have. Nevertheless, the high value of the coefficient $\beta$ gives us reasonable confidence to use the insurance claim dummy as a measure of distress. 
Table 1

Claims Filed and the Probability of Default

\begin{tabular}{lccc}
\hline & $(1)$ & $(2)$ & $(3)$ \\
\hline Insurance-claim dummy & $.62^{* *}$ & $.57^{* *}$ & $.57^{* *}$ \\
& $(.11)$ & $(.11)$ & $(.11)$ \\
Log loan amount & & $.36^{* *}$ & $.36^{* *}$ \\
& & $(.02)$ & $(.02)$ \\
Standardized kharif rain & & & $.06^{+}$ \\
& & & $(.03)$ \\
\hline
\end{tabular}

Note. Results are from ordinary least squares regressions. The dependent variable is a dummy that equals one if a borrower defaults and zero otherwise. All regressions include borrower and year fixed effects. Standard errors clustered at the borrower level are in parentheses. $N=2,927$.

+ Significant at the $10 \%$ level.

${ }^{* *}$ Significant at the $1 \%$ level.

\subsection{Descriptive Statistics}

Table 2 reports statistics for the size of loans, the number of loans issued to a borrower, the probability of default, and the payout received conditional on a claim being filed. A total of 57 percent of the borrowers file an insurance claim in our sample: these constitute our distressed borrowers. Note that the claim amount is, however, 8 percent (5 percent) of the loan amount using the mean (median) values. Thus, while the insurance claim enables us to proxy borrowers' distress, it does not alleviate distress significantly.

\section{Empirical Strategy and Results}

\subsection{Challenges to Identification}

The key empirical challenge stems from the fact that the unobserved quality of borrowers affects the likelihood of default and thereby eligibility for the waiver program. Borrowers' unobserved quality also influences subsequent performance on loans because bad-quality borrowers may either be unproductive or divert their loans to unproductive uses. So this omitted variable affects the likelihood of treatment and any outcome variable. Thus, empirical strategies that cannot control for borrowers' unobserved quality suffer from this endogeneity problem.

\subsection{The Regression Discontinuity Design}

To overcome these challenges to identification, we employ an $\mathrm{RD}$ design that exploits two unique features of the program: First, as argued in Section 3.3 and by Giné and Kanz (2018), the debt waiver scheme was unanticipated. Second, borrowers had no opportunity to strategically manipulate their way into the treatment group.

In the $\mathrm{RD}$ design, we restrict attention to a subset of borrowers who defaulted 
Table 2

Summary Statistics for the Regression Discontinuity Sample, 2005-12

\begin{tabular}{lrrr}
\hline & Mean & Median & \multicolumn{1}{c}{ SD } \\
\hline Total loans & 3.68 & 4.00 & 1.38 \\
Loan amount (INR) & $36,882.55$ & $28,311.86$ & $31,465.05$ \\
Probability of default & .62 & 1.00 & .49 \\
Waiver-beneficiary dummy & .85 & 1.00 & .36 \\
Farmer-has-insurance dummy & .57 & 1.00 & .49 \\
Probability of purchasing insurance (prewaiver period) & .91 & 1.00 & .86 \\
Probability of filing a claim (prewaiver period) & .64 & .00 & .92 \\
Premium amount (INR) & 987.69 & 306.50 & $1,853.17$ \\
Claim amount (INR) & 962.84 & .00 & $3,233.98$ \\
\hline
\end{tabular}

Note. The insurance sample excludes borrowers for whom insurance information is not available before the waiver program was implemented. $N=10,570$ loans.

on their existing loans during the period December 2007-January 2008. As described in Section 1, the empirical strategy exploits the unique feature that borrowers had to be in default on their outstanding loans as of December 31, 2007. Farmers who defaulted before this cutoff date were eligible to become beneficiaries of the program, but those who defaulted after the cutoff date were not. The cutoff date creates a sharp discontinuity in the treatment status. Our classification scheme thus reduces endogeneity concerns caused by borrowers' unobserved heterogeneity.

Identification using the $\mathrm{RD}$ design rests on the assumption that borrowers are assigned to the eligibility group solely on the basis of a continuous forcing variable (or selection variable) $s$. The observations can then be categorized into two levels of treatments according to whether the observed value of the forcing variable exceeds an exogenous threshold $\bar{s}$. The selection variable in our setup equals the number of days before or after the cutoff date (December 31,2007) when the loan became delinquent; thus, we set the exogenous cutoff as $\bar{s}=0$. This characterization yields a simple rule for the discontinuity analysis:

$$
t_{i}=t\left(s_{i}\right)=\left\{\begin{array}{ll}
1 & \text { if } s_{i} \leq 0 \\
0 & \text { if } s_{i}>0
\end{array} .\right.
$$

Consider the farmer who obtained an agricultural loan on December 10, 2006. The loan is in default if it is not repaid by December 9, 2007. For this loan, $s_{i}=$ -21 . Thus, loans that became delinquent before December 31, 2007, have a negative value for the selection variable. In contrast, loans that defaulted in January 2008 will have a positive value. Thus, the treatment variable correlates perfectly with the status as a waiver beneficiary.

The causal effect of the debt waiver on loan performance can be estimated as the discontinuity in the conditional expectations of the outcome variable at the cutoff: 


$$
\tau_{\mathrm{RD}}=\lim _{s \downarrow \bar{s}} \boldsymbol{E}\left(Y_{i} \mid S_{i}=s\right)-\lim _{s \uparrow \bar{s}} \boldsymbol{E}\left(Y_{i} \mid S_{i}=s\right) .
$$

Intuitively, if farmers who default around the cutoff date receive similar sets of shocks and do not differ in observed prewaiver characteristics, then the difference in ex post outcomes can be attributed to the borrower's treatment status. To estimate this causal effect, we run local linear regressions for postwaiver loan performance using the specification

$$
y_{i t}=\gamma_{0}+\tau_{\mathrm{RD}} \times t_{i}+\gamma_{1} \times f\left(s_{i}\right)+\gamma_{2} \times\left[t_{i} \times f\left(s_{i}\right)\right]+\beta_{k} \times \beta_{t}+\Gamma \times \boldsymbol{X}_{i}+\varepsilon_{i t},
$$

where $y_{i t}$ is a dummy variable that equals one if the loan under consideration issued to borrower $i$ in year $t$ after the waiver defaults and zero otherwise, $t_{i}$ is the treatment dummy defined in equation (3), $f\left(s_{i}\right)$ is a polynomial function of the forcing variable, and $\beta_{k} \times \beta_{t}$ denote fixed effects for each branch-year. Thus, we estimate the RD model by exploiting variation in waiver status in each branchyear. This variation arises because of the difference in the default status of the loan as of December 31, 2007, in each branch-year. The term $\boldsymbol{X}_{i}$ denotes a vector of controls that includes loan size and average rainfall during the loan period. We include these controls because they significantly affect the probability of default. The main coefficient of interest is $\tau_{\mathrm{RD}}$, which captures the local average treatment effect (LATE) as defined in equation (4). We estimate both ordinary least squares (OLS) and probit regressions on a narrow bandwidth of length $h \in[-30,30]$ around the cutoff point and cluster the standard errors at the branch-year level.

We focus on borrowers who defaulted around the cutoff date and consider a subset of farmers who purchased crop insurance on their loans prior to announcement of the waiver. We do not, however, require the borrowers to buy insurance during the postwaiver period. As argued in Section 5.4, this could generate potential selection biases due to moral hazard stemming from the insurance contract. We cannot run specifications that include borrower fixed effects because the sample includes only the loans issued after the waiver program was implemented. The fixed effects would exclude borrowers who had only one loan in the postwaiver period and would create potential selection problems because those borrowers may be different from borrowers who received multiple loans in the postwaiver period. In contrast, our sample exhibits no such differences, as we highlight in Section 6.4.

\subsection{Regression Discontinuity Estimates for the Effect of Waivers on Repayment of Loans}

We begin by presenting graphical evidence in Figure 3, which shows the RD design by plotting the probability of default ( $y$ equals one if the borrower defaults and zero otherwise) during the postwaiver period around the cutoff point. The $X$-axis represents the selection variable, measured as the number of days relative to the cutoff date of December 31, 2007, when the last loan originated during the prewaiver period becomes delinquent. On the $Y$-axis, we plot the average of the 

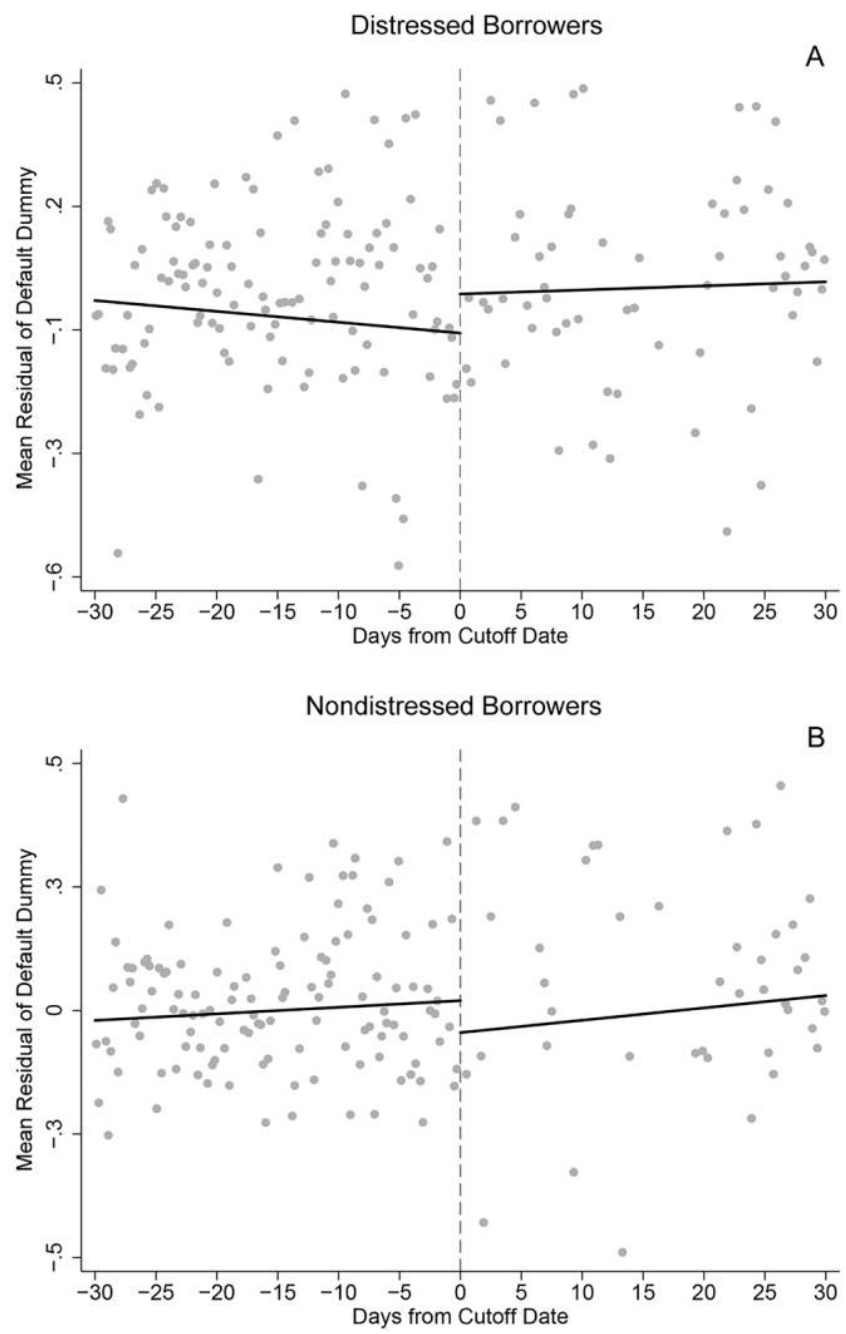

Figure 3. Ex post probability of default

probability of default for the loans originated during the postwaiver period. Each point represents the average of the probability of default in bins of 1 day. The solid line represents the fitted value of a linear function of the forcing variable.

The outcome variable of interest captures the likelihood of default on loans originated after the waiver program given to the same set of borrowers who had defaulted before the waiver program. In Figure $3 A$, we restrict the sample to distressed borrowers who defaulted on their prewaiver loans. Borrowers on the left of the cutoff date are waiver beneficiaries, and those on the right are comparable nonbeneficiaries. The sharp discontinuity with a positive intercept at the cutoff 
Table 3

Ex Post Probability of Default

\begin{tabular}{lcccccc}
\hline & \multicolumn{2}{c}{ Distressed Borrowers } & & \multicolumn{2}{c}{ Nondistressed Borrowers } \\
\cline { 2 - 3 } \cline { 6 - 7 } & $(1)$ & $(2)$ & & $(3)$ & $(4)$ \\
\hline Waiver beneficiaries & $-.09^{* *}$ & $-.08^{* *}$ & & $.23^{\star}$ & $.23^{\star}$ \\
& $(.016)$ & $(.015)$ & & $(.085)$ & $(.079)$ \\
$N$ & 1,783 & 1,783 & & 1,560 & 1,560 \\
$R^{2}$ & .566 & .567 & & .570 & .570 \\
Controls & No & Yes & & No & Yes \\
\hline
\end{tabular}

Note. Results are from ordinary least squares regressions; the dependent variable is a dummy that takes the value one if a borrower defaults and zero otherwise. The local average treatment effect is captured by the coefficient of the treatment dummy, which equals one for negative values of the forcing variable and zero otherwise. The correlation between treatment status based on regression discontinuity rule and waiver status is 1 . All regressions include branchyear fixed effects. Standard errors clustered at the branch-year level are in parentheses.

* Significant at the $5 \%$ level.

** Significant at the $1 \%$ level.

implies that the probability of default for distressed waiver beneficiaries is significantly lower than that of comparable nonbeneficiaries.

In Figure $3 B$, which has a sample restricted to nondistressed borrowers, with waiver beneficiaries on the left side of the cutoff date and nonbeneficiaries on the right. There is a sharp discontinuity in the opposite direction of that for distressed borrowers. The intercept at the cutoff has a negative sign, which implies that the postwaiver default rate of nondistressed waiver beneficiaries is significantly higher than that of nonbeneficiaries.

We present the results of formal RD tests in Table 3, which. shows estimates of equation (5) in an OLS model. Following the suggestion made by Gelman and Imbens (forthcoming), we restrict the degree of the polynomial function to 2 to capture any plausible nonlinear effects. However, the results are robust to a change in the degree of the polynomial function. Regressions that include loanand branch-level variables account for the effect of rainfall and loan size.

Table 3, in line with Figure 3A, indicates that distressed waiver beneficiaries default at significantly lower rates than comparable distressed nonbeneficiaries. For distressed borrowers, we find that the probability of default decreased by 9 percent after implementation of the waiver program. Clearly, the change is economically meaningful. In line with the results presented in Figure $3 B$, we find that the nondistressed waiver beneficiaries default 23 percent more than comparable nondistressed nonbeneficiaries. As an additional robustness test, we repeat the $\mathrm{RD}$ test using probit regressions and report the results in Table OC1 in Online Appendix. The results remain largely unchanged.

These results are in line with the hypotheses presented in Section 4. Borrowers who defaulted in the prewaiver period because of exogenous liquidity shocks outperform comparable distressed borrowers after a debt waiver. However, the op- 
posite occurs when a waiver is awarded to nondistressed borrowers, who either default strategically or for reasons relating to borrowers' credit quality.

\subsection{Checking the Internal Validity of the Regression Discontinuity Design}

Validity of the RD design rests on two critical identifying assumptions. First, the selection variable should not show a discontinuous jump around the cutoff point; that is, there is no threat of potential manipulation of treatment status around the cutoff point. Second, important observable characteristics do not show any discontinuity around the cutoff point.

\subsubsection{Potential Manipulation into Treatment}

If borrowers could anticipate the timing and the eligibility status of the debt waiver program ex ante, they could have timed their loans accordingly. However, for reasons discussed in Section 3.3, we do not expect such manipulation to be a serious threat to identification. Figure 4 shows that the $\mathrm{RD}$ design is not affected by endogenous selection into treatment by waiver beneficiaries. In Figure $4 A$, which plots the density of borrowers who default around the cutoff date, we do not observe a higher density of borrowers on the left of the cutoff point $\left(s_{i} \leq \bar{s}\right)$ that corresponds to waiver beneficiaries. The McCrary (2008) test reveals no observable discontinuity around the cutoff point (Figure $4 B$ ). The proportion of borrowers on the right side of the cutoff date does not appear to be any different than that on the left side, which alleviates concerns about possible manipulation into the program.

\subsubsection{Possible Discontinuity in Other Observable Characteristics}

We now examine if key observable characteristics prior to the waiver program exhibit discontinuity around the cutoff point. Figure 5 plots against the selection variable the means of average loan size before the waiver program and average loan size after the waiver program; Figure 6 plots the average insurance premium paid and average insurance claim received. We notice no discontinuity in any of the variables. Crucially, it is reassuring to find no discontinuity in either the insurance premium paid or the payout received. Thus, as a proxy for borrowers' distress, filing an insurance claim does not correlate systematically with a waiver.

\subsection{Corroborative Evidence Using Local Area Weather Shocks}

Our crop-insurance-based measure of distress varies at the individual level and hence is likely to capture distress reasonably well. Even if this borrower-level proxy contains some measurement error, it is unlikely to vary systematically with the exogenous cutoff date for the waiver. In particular, for the measurement error in the proxy to affect our results, the following conditions must simultaneously hold. First, the measurement error must have a systematically lower correlation with the probability of default by distressed waiver beneficiaries than by com- 
Density of Observations

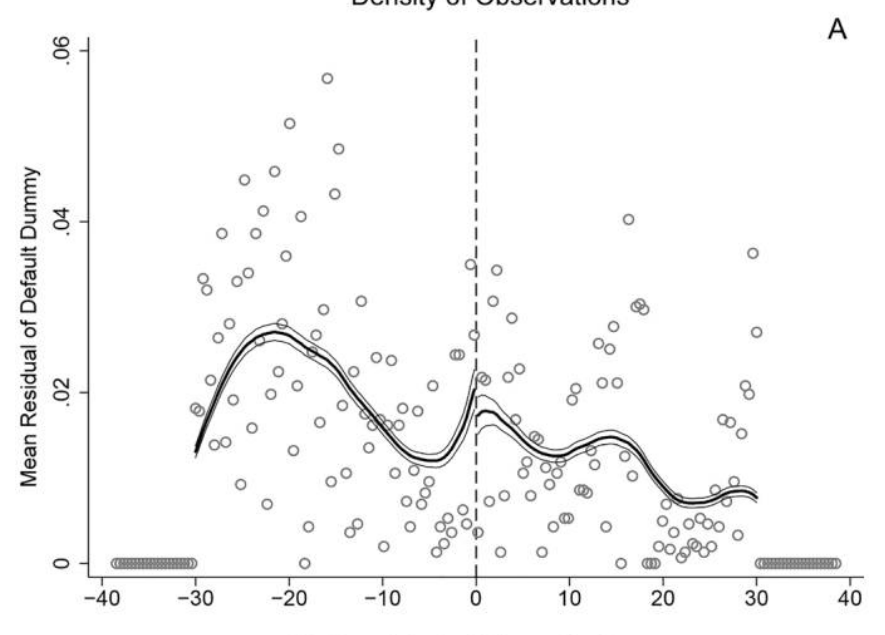

McCrary Test of Discontinuity

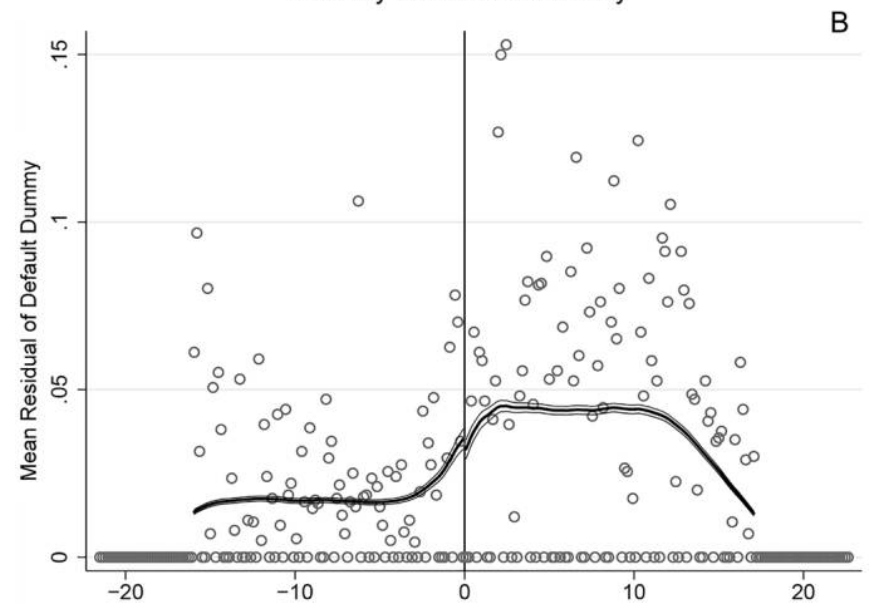

Figure 4. Density of default around the cutoff date

parable distressed nonbeneficiaries. Second, the measurement error must have a systematically higher correlation with the probability of default by nondistressed waiver beneficiaries than by comparable nondistressed nonbeneficiaries. Such systematic correlations of the measurement error are implausible, especially given the exogenous cutoff date that separates beneficiaries and nonbeneficiaries.

Nonetheless, to ascertain further the robustness of our results, we examine our results using a measure of distress that varies geographically according to the local area's weather (rather than at the borrower level). We label a borrower as distressed if the area in which he resides faces drought immediately before the waiver program. 


\section{Prewaiver Loans}

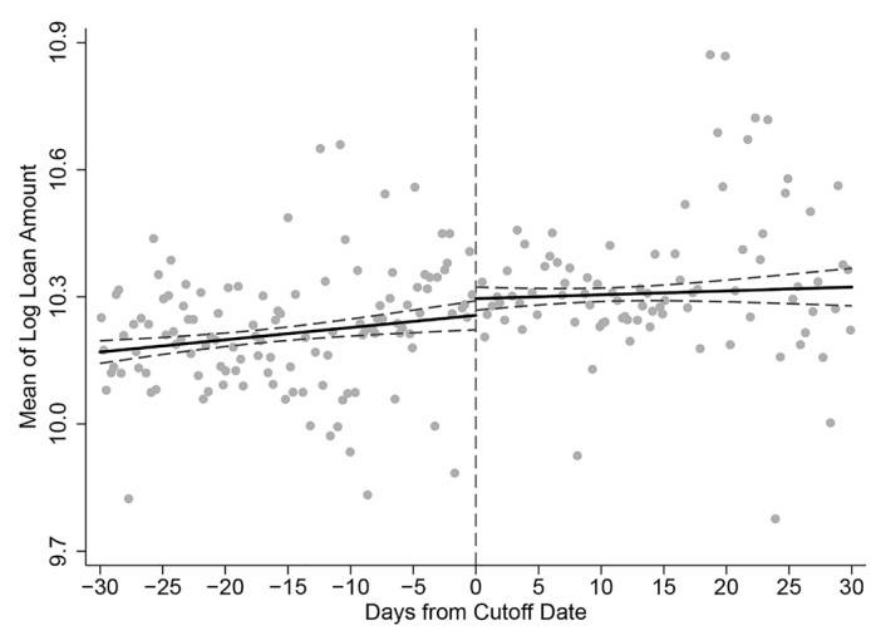

Postwaiver Loans

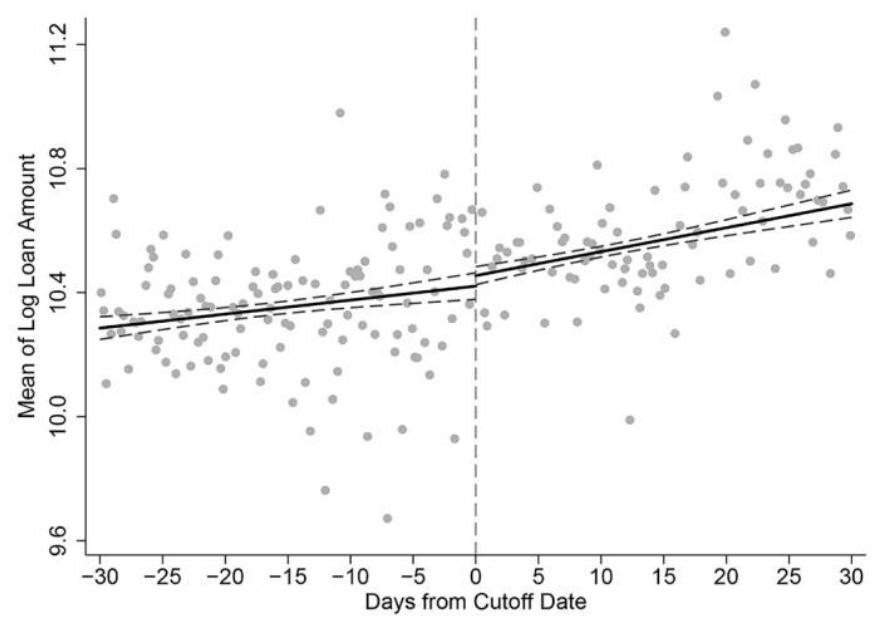

Figure 5. Continuity of loan amounts around the cutoff date

In these tests, we use the incidence of drought in an area covered by a bank branch to identify distressed and nondistressed borrowers. We first identify the geographic location of a branch and collect data on rainfall there. The monthly precipitation data are from Matsuura and Wilmott (2015). The data provide longterm monthly rainfall amounts on a $.5 \times .5$ latitude-longitude grid for the years 1900-2014. We match the data on rainfall to the branch locations using latitude and longitude data from the geographic information system map. To construct 


\section{Prewaiver Log Premium Paid}

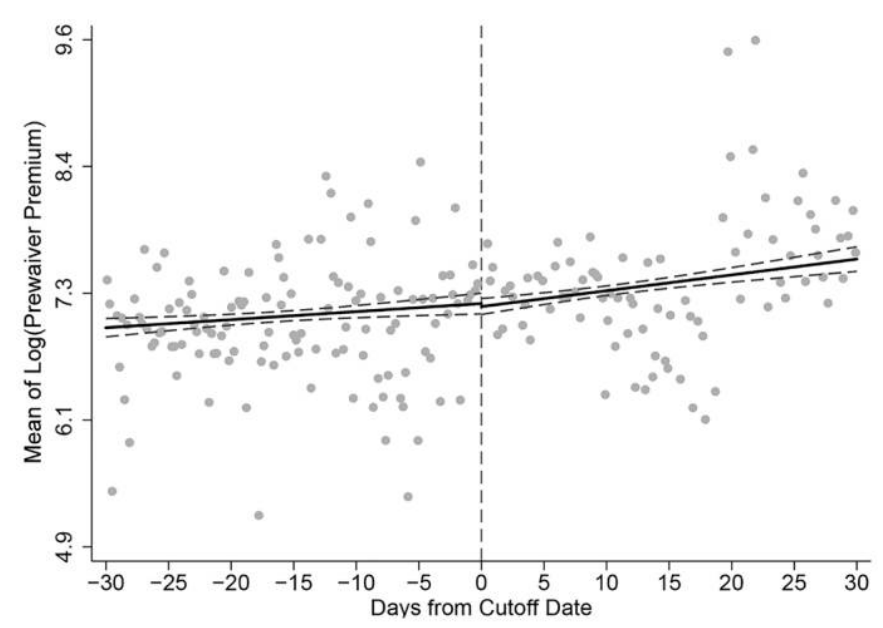

\section{Prewaiver Log Claim Received}

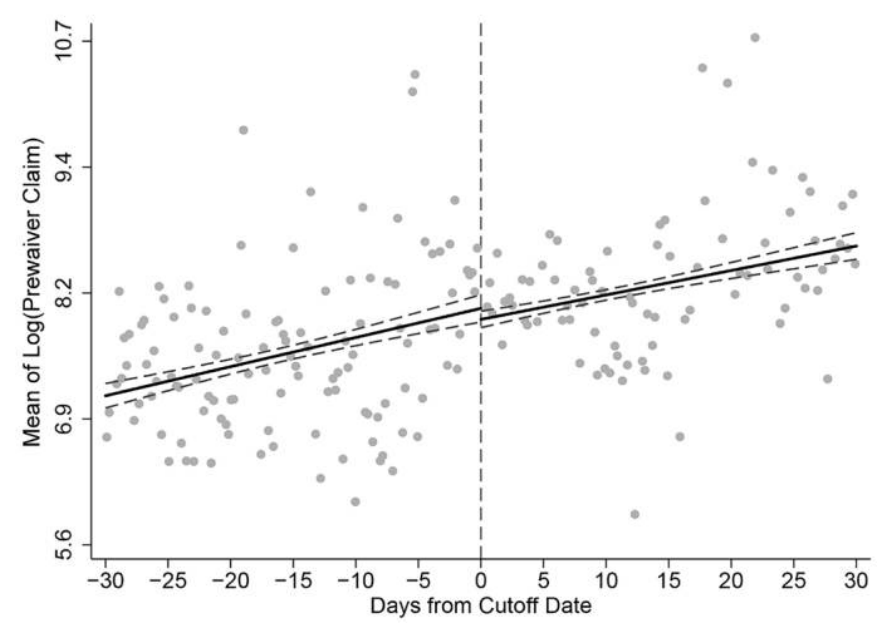

Figure 6. Continuity of insurance amounts around the cutoff date

the drought variable, we follow the percentage-of-normal method in Burgess et al. (2011). We compare the average rainfall for an area in the first 6 months after a loan is granted with its long-term average (LTA). We use the first 6 months after a loan is granted because the weather during the time when the crop is sowed matters most for the productivity of the crop. The LTA values are calculated using rainfall data for the previous 30 years (1975-2005). If the measured value falls short of a certain cutoff percentage of the LTA, the area is said to be suffering 
Table 4

Ex Post Probability of Default Using Exogenous Drought Shocks

\begin{tabular}{lcccccc}
\hline & \multicolumn{2}{c}{ Distressed Borrowers } & & \multicolumn{2}{c}{ Nondistressed Borrowers } \\
\cline { 2 - 3 } \cline { 6 - 7 } & $(1)$ & $(2)$ & & $(3)$ & $(4)$ \\
\hline Waiver beneficiaries & $-.22^{\star *}$ & $-.22^{\star *}$ & & $.20^{* \star}$ & $.21^{\star *}$ \\
& $(.030)$ & $(.034)$ & & $(.036)$ & $(.042)$ \\
$N$ & 2,958 & 2,958 & & 1,213 & 1,213 \\
$R^{2}$ & .562 & .562 & & .373 & .374 \\
Controls & No & Yes & & No & Yes \\
\hline
\end{tabular}

Note. Results are marginal effects from ordinary least squares regressions; the dependent variable is a dummy that equals one if a borrower defaults and zero otherwise. The local average treatment effect is captured by the coefficient of the treatment dummy, which equals one for negative values of the forcing variable and zero otherwise. The correlation between treatment status based on regression discontinuity rule and waiver status is 1 . All regressions employ branch-year fixed effects. Standard errors clustered at the branch-year level are in parentheses.

${ }^{* *}$ Statistically significant at the 1 percent level.

from drought. Following Pai et al. (2011), we use 80 percent as the designated cutoff. Thus, the drought variable for a loan originated in branch $k$ in month $m$ and year $t$ equals one if

$$
\text { Drought }_{k m t}=1 \Leftrightarrow \bar{r}_{k m t} \leq .8 \times \bar{r}_{k},
$$

with

$$
\bar{r}_{k m t}=\frac{1}{6} \sum_{i=1}^{i=6} r_{k, m+i, t} \quad \text { and } \quad \bar{r}_{k}=\frac{1}{N} \sum_{i=1}^{i=N} r_{k, 2005-i},
$$

where $\bar{r}_{k}$ and $\bar{r}_{k m t}$ are the long-term average and average kharif rainfall. We report the results of OLS regressions in Table 4. We find similar results using the branch-level measure for distress. These tests include branch-year fixed effects to absorb omitted variables at the branch-year level. Note that our branch-level measure of distress exhibits variation in a branch-year, as we use the average rainfall in the first 6 months after a loan is originated. This allows us to estimate the results using branch-year fixed effects. These results provide further comfort that our results for the differing effects on distressed and nondistressed borrowers are unlikely to stem from measurement error in our insurance-based proxies.

\section{Possible Selection Effects}

As in previous studies (Kanz 2016; Giné and Kanz 2018; De and Tantri 2014), we observe equilibrium outcomes. Therefore, it is crucial to examine the possible effects of sample selection on our main results. Two forms of selection concern us. First, in general, waiver beneficiaries and nonbeneficiaries may differ in the probability of obtaining a fresh loan after the waiver, on the extensive margin, and the loan's amount, on the intensive margin. As these differences do not pertain differentially to distressed and nondistressed borrowers, we refer to this form as general selection. However, as our key results pertain to the differential impact 
Table 5

Probability of Borrowing during the Postwaiver Period

\begin{tabular}{lccccc}
\hline & Full Sample & $\begin{array}{c}\text { Distressed } \\
\text { Borrowers } \\
(1)\end{array}$ & $\begin{array}{c}\text { Nondistressed } \\
\text { Borrowers } \\
(2)\end{array}$ & $\begin{array}{c}\text { All Insured } \\
(4)\end{array}$ & $\begin{array}{c}\text { Uninsured } \\
(5)\end{array}$ \\
\hline Waiver beneficiaries & -.02 & -.04 & .04 & -.02 & -.01 \\
$N$ & $(.70)$ & $(.20)$ & $(.75)$ & $(.69)$ & $(.79)$ \\
$N$ & 5,794 & 1,757 & 496 & 2,253 & 3,539 \\
\hline
\end{tabular}

Note. Results are from ordinary least squares regressions; the dependent variable is a dummy that equals one if the borrower obtains a loan in the postwaiver period and zero otherwise. The local average treatment effect is captured by the coefficient of the waiver-beneficiaries dummy, which equals one for positive values of the forcing variable and zero otherwise. The correlation between treatment status based on regression discontinuity rule and waiver status is 1 . Standard errors clustered at the branch-year level; $p$-values are in parentheses.

of a debt waiver on distressed and nondistressed borrowers, the existence of general selection is not sufficient to spoil the interpretation of our results. Consider the effects from the supply side. If a loan officer is relatively more stringent with waiver beneficiaries while granting loans in the postwaiver period, such general selection can explain only relatively lower rates of default among distressed borrowers but not the relatively higher rates of default among nondistressed borrowers. Therefore, for selection effects to spoil the interpretation of our results, they must manifest in opposite directions for distressed and nondistressed borrowers. Thus, the loan officer must be more stringent with waiver beneficiaries than nonbeneficiaries among distressed borrowers and less stringent with beneficiaries than nonbeneficiaries among nondistressed borrowers. Similar arguments can be provided from the demand side. To distinguish such selection from general selection, we label it differential selection. We alleviate concerns about differential selection by appealing to the institutional setting and by conducting $\mathrm{RD}$ tests.

Two institutional features noted in Sections 3.1.3 and 3.1.4 alleviate concerns relating to selection. First, crop loans are made at a rate that is lower than the risk-free rate (and significantly lower than normal bank lending rates). Therefore, demand for loans is unlikely to differ between waiver beneficiaries and nonbeneficiaries. Second, under priority-sector lending mandated by law, Indian banks are required to allocate at least 18 percent of their credit to agriculture. Failure to comply with this requirement not only leads to a penalty for the bank but also negatively impacts loan officers' performance assessments (Bhowal, Subramanian, and Tantri 2013). Therefore, general selection is unlikely in our sample.

Nevertheless, we perform an RD test to examine both forms of selection. To test whether a borrower receives a loan after the waiver program was implemented, we organize the data at the borrower level and not at the borrower-loan level. The null hypothesis here is that the likelihood of obtaining a loan and the amount of the loan are identical for waiver beneficiaries and nonbeneficiaries. Thus, a precisely estimated difference of 0 between beneficiaries and nonbeneficiaries would provide evidence that selection is not operative in our setting. We report the results in Table 5. In column 1, we consider the full sample of borrow- 
ers to examine general selection. We cannot reject the hypothesis that the difference between waiver beneficiaries and nonbeneficiaries in the probability of obtaining a loan in the postwaiver period is 0 . Given the mean and standard error of -3 percent and 5 percent, respectively, the 95 percent confidence interval equals $[-12.8,6.8]$. Admittedly, the large confidence intervals indicate that this test does not provide a precise estimate of no difference between the beneficiaries and nonbeneficiaries.

In columns 2 and 3, we examine the differences for the sample of distressed and nondistressed borrowers according to the status of their insurance claims (as in our main analysis). In both subsamples, we are unable to reject the null hypothesis that the difference between beneficiaries and nonbeneficiaries is 0 . Given their means and standard errors, the 95 percent confidence intervals equal $[-2.8,8.8]$ and $[-4.8,14.8]$ for distressed and nondistressed borrowers, respectively. While these confidence intervals are large, differential selection can spoil the interpretation of our results if-in the extreme case-distressed waiver beneficiaries are 2.79 percent (slightly more than the 95 percent confidence interval of -2.8 ) less likely to obtain a loan after the waiver while, at the same time, nondistressed waiver beneficiaries are 14.79 percent more likely to obtain a loan, both when compared with identical nonbeneficiaries. These estimates of the extreme values assume that the following phenomena manifest. If selection manifests from the supply side, the loan officer will be more stringent in providing loans in the postwaiver period to distressed beneficiaries and simultaneously less stringent to nondistressed beneficiaries (both when compared with similar nonbeneficiaries). If selection manifests from the demand side, lower-quality distressed borrowers and higher-quality nondistressed borrowers are less likely to approach the bank for a loan in the postwaiver period (again, when compared with similar borrowers who did not receive waivers). While the large confidence intervals render the $\mathrm{RD}$ tests as suggestive evidence, taken together with the institutional setup and the need for differential selection, we conclude that selection may not be accounting for our results. ${ }^{9}$

We also examine the differences at the intensive margin, that is, loan amounts for loans taken after the waiver program was implemented. We report the results in Table OC2 in the Online Appendix. Here too, we do not find any significant difference between the waiver beneficiaries and nonbeneficiaries. Finally, we repeat the $\mathrm{RD}$ test examining the probability of a loan being granted in the postwaiver period using probit regressions and find similar results in Table OC3 in the Online Appendix. These results further support our hypothesis that selection of borrowers after the waiver program was implemented is unlikely to impact our results significantly.

\footnotetext{
${ }^{9}$ In column 4 , we repeat the test using the sample of borrowers who had crop insurance. For completion, in column 5, we use the sample of borrowers who did not have crop insurance and hence are excluded from our main tests. These borrowers, however, are included in tests reported in Table 4, where we proxy distress using branch-level rainfall. Our main tests are based on the loan performance of these borrowers. We find no significant difference between waiver beneficiaries and nonbeneficiaries.
} 


\section{Conclusion}

We examine the causal effect of debt relief on the loan performance of distressed and nondistressed borrowers by utilizing the $\$ 14.4$ billion debt waiver program in India in 2008. We combine unique loan-level data with an RD design that exploits exogenous cutoff dates to compare waiver beneficiaries with similar nonbeneficiaries. Our results are consistent with the hypothesis that debt relief improves the loan repayment behavior of distressed borrowers. However, debt relief extended to nondistressed borrowers adversely impacts their loan repayment behavior. Thus, our results highlight the need for separating distressed and nondistressed beneficiaries when assessing the effects of a debt waiver and carefully targeting debt relief programs to benefit distressed borrowers.

\section{References}

Agarwal, Sumit, Gene Amromin, Itzhak Ben-David, Souphala Chomsisengphet, Tomasz Piskorski, and Amit Seru. 2017. Policy Intervention in Debt Renegotiation: Evidence from the Home Affordable Modification Program. Lournal of Political Economv 125:654-712.

Athreya, Kartik B. 2002. Welfare Implications of the Bankruptcy Reform Act of 1999. Lournal of Monetary Economics 49:1567-95.

Banerjee, Abhijit V., and Andrew F. Newman. 1993. Occupational Choice and the Process of Development. Iournal of Political Economv 101:274-98.

Bhowal, Subhendu, Krishnamurthy Subramanian, and Prasanna L. Tantri. 2013. Soft Information and the Cost of Job Rotation: Evidence from Loan Officer Rotation. Working Paper No. 2362104. Indian School of Business, Hyderabad.

Bhue, Gursharan Singh, N. R. Prabhala, and Prasanna Tantri. 2015. Creditor Rights and Relationship Banking: Evidence from a Policy Experiment. Unpublished manuscript. Indian School of Business, Hyderabad.

Bolton, Patrick, and Howard Rosenthal. 2002. Political Intervention in Debt Contracts. Lournal of Political Economy 110:1103-34.

Burgess, Robin, Olivier Deschenes, Dave Donaldson, and Michael Greenstone. 2011. Weather and Death in India. Working paper. London School of Economics, London.

Carleton, Tamma A. 2017. Crop-Damaging Temperatures Increase Suicide Rates in India. Proceedings of the National Academy of Sciences of the United States of America 114: 8746-51.

Chatterjee, Satyajit, and Grey Gordon. 2012. Dealing with Consumer Default: Bankruptcy vs Garnishment. Lournal of Monetary Economics 59:S1-S16.

Cohen-Cole, Ethan, Burcu Duygan-Bump, and Judit Montoriol-Garriga. 2009. Forgive and Forget: Who Gets Credit after Bankruptcy and Why? Working Paper No. QAU092. Federal Reserve Bank of Boston, Boston.

Damodaran, Harish. 2016. Some Assurance: How New Crop Insurance Scheme Can Be a Game-Changer. Indian Express, January 21.

Datt, Gaurav, and Hans Hoogeveen. 2003. El Niño or El Peso? Crisis, Poverty, and Income Distribution in the Philippines. World Development 31:1103-24.

De, Sankar, and Prasanna L. Tantri. 2014. Borrowing Culture and Debt Relief: Evidence from a Policy Experiment. Paper presented at the 2014 conference of the Asian Finance 
Association, Bali, June 24-27.

Deaton, Angus. 1989. Saving in Developing Countries: Theory and Review. World Bank Economic Review 3:61-96.

2016. Measuring and Understanding Behavior, Welfare, and Poverty. American Economic Review 106:1221-43.

Demiroglu, Cem, Evan Dudley, and Christopher M. James. 2014. State Foreclosure Laws and the Incidence of Mortgage Default. Lournal of Law and Economics 57:225-80.

Dick, Astrid A., and Andreas Lehnert. 2010. Personal Bankruptcy and Credit Market Competition. Lournal of Finance 65:655-86.

Dobbie, Will, and Jae Song. 2015. Debt Relief and Debtor Outcomes: Measuring the Effects of Consumer Bankruptcy Protection. American Economic Review 105:1272-1311.

Dubey, Pradeep, John Geanakoplos, and Martin Shubik. 2005. Default and Punishment in General Equilibrium. Econometrica 73:1-37.

Economic Times (India). 2016. Big Gap in Per Capita Income in Urban and Rural Areas. May 10.

Firstpost. 2016. Manmohan Singh vs Modi: Whose Crop Insurance Is Better? January 15.

Gelman, Andrew, and Guido Imbens. Forthcoming. Why High-Order Polynomials Should Not Be Used in Regression Discontinuity Designs. Journal of Business and Economic Statistics.

Giné, Xavier, and Martin Kanz. 2018. The Economic Effects of a Borrower Bailout: Evidence from an Emerging Market. Review of Financial Studies 31:1752-83.

Goodman, Joshua, and Adam Levitin. 2014. Bankruptcy Law and the Cost of Credit: The Impact of Cramdown on Mortgage Interest Rates. Lournal of Law and Economics 57:139-58.

Guiso, Luigi, Paola Sapienza, and Luigi Zingales. 2013. The Determinants of Attitudes toward Strategic Default on Mortgages. Lournal of Finance 68:1473-1515.

Hahn, Jinyong, Petra Todd, and Wilbert Van der Klaauw. 2001. Identification and Estimation of Treatment Effects with a Regression-Discontinuity Design. Econometrica 69:201-9.

Hindu. 2008. ICICI Bank Returns Tractor to Farmer's Mother. June 30.

Imbens, Guido W., and Thomas Lemieux. 2008. Regression Discontinuity Designs: A Guide to Practice. Lournal of Econometrics 142:615-35.

Jacoby, Hanan G., and Emmanuel Skoufias. 1997. Risk, Financial Markets, and Human Capital in a Developing Country. Review of Economic Studies 64:311-35.

Kanz, Martin. 2016. What Does Debt Relief Do for Development? Evidence from India's Bailout for Rural Households. American Economic Journal: Applied Economics 8:66-99.

Kaplan, Greg, and Giovanni L. Violante. 2014. A Model of the Consumption Response to Fiscal Stimulus Payments. Econometrica 82:1199-1239.

Kroszner, Randall S. 2003. Is It Better to Forgive than to Receive? An Empirical Analysis of the Impact of Debt Repudiation. Working paper. University of Chicago, Graduate School of Business, Chicago.

Lee, David S., and Thomas Lemieux. 2010. Regression Discontinuity Designs in Economics. Journal of Economic Literature 48:281-355.

Livshits, Igor, James MacGee, and Michèle Tertilt. 2007. Consumer Bankruptcy: A Fresh Start. American Economic Review 97:402-18.

Mahadevan, Renuka, and Sandy Suardi. 2013. Is There a Role for Caste and Religion in Food Security Policy? A Look at Rural India. Economic Modelling 31:58-69.

Matsuura, Kenji, and Cort J. Willmott. 2015. Terrestrial Precipitation: 1900-2014 Grid- 
ded Monthly Time Series, ver. 4.01. http://climate.geog.udel.edu/ climate/html_pages /Global2014/README.GlobalTsP2014.html.

Mayer, Christopher, Edward Morrison, Tomasz Piskorski, and Arpit Gupta. 2014. Mortgage Modification and Strategic Behavior: Evidence from a Legal Settlement with Countrywide. American Economic Review 104:2830-57.

McCrary, Justin. 2008. Manipulation of the Running Variable in the Regression Discontinuity Design: A Density Test. Journal of Econometrics 142:698-714.

Mian, Atif, and Amir Sufi. 2014. House of Debt: How They (and You) Caused the Great Recession, and How We Can Prevent It from Happening Again. Chicago: University of Chicago Press.

Ministry for Agriculture and Farmers Welfare. 2000. Pradhan Mantri Fasal Bima Yojana (PMFBY). New Delhi: Department of Agriculture. https://pmfby.gov.in/pdf/New\%20 Schemes-english_.pdf.

Mookherjee, Dilip, and Debraj Ray. 2003. Persistent Inequality. Review of Economic Studies 70:369-93.

Pai, D. S., Latha Sridhar, Pulak Guhathakurta, and H. R. Hatwar. 2011. District-wide Drought Climatology of the Southwest Monsoon Season over India Based on Standardized Precipitation Index (SPI). Natural Hazards 59:1797-1813.

Reserve Bank of India. 2004. Annual Policy Statement for the Year 2004-05: Prudential Norms for Agricultural Advances. July 1. Mumbai. https://rbidocs.rbi.org.in/rdocs /Notification/PDFs/55002.pdf.

- 2008. RBI Releases Report of Its Internal Working Group on Radhakrishna Report. Press release, April 25. https://rbi.org.in/Scripts/BS_PressReleaseDisplay.aspx ?prid=18224.

Rucker, Randal R., and Lee J. Alston. 1987. Farm Failures and Government Intervention: A Case Study of the 1930's. American Economic Review 77:724-30.

Skeel, David A., Jr. 2001. Debt's Dominion: A History of Bankruptcy Law in America. Princeton, NJ: Princeton University Press.

Tabb, Charles J. 1995. The History of the Bankruptcy Laws in the United States. American Bankruptcy Institute Law Review 3:5-51.

United Nations Commission on Sustainable Development. 2008. International Farmers Suicide Crisis. Report presented at the 16th session of the Commission on Sustainable Development, New York, May 5-16. https://sustainabledevelopment.un.org/content /sustdev/csd/csd16/PF/presentations/farmers_relief.pdf.

White, Michelle J. 1998. Why Don't More Households File for Bankruptcy? Lournal of Law, Economics, and Organization 14:205-31.

. 2007. Bankruptcy Reform and Credit Cards. Lournal of Economic Perspectives 21:175-200.

World Bank. 2012. Doing Business 2012: Doing Business in a More Transparent World. Washington, DC: International Bank for Reconstruction and Development and the World Bank. 